\title{
Research on Fault Tolerant Strategy and Reliability of Steering-by-Wire
}

\author{
Zhongyi Hu, Fengdeng Zhang, and Zhiqiang Wei
}

\begin{abstract}
In this paper, we introduce a methodology for the reliability analysis of the redundant steering-by-wire system. With rapid development of modern automotive electronics and deep electronic degree, it is necessary to analyze the reliability of system to fully understand and quantify the failure mechanisms in order to improve the design. Several system level FMEAs are used to identify the different failure times of system and a markov model is constructed to quantify their probability of occurrence. For the safety-critical real-time system, the redundancy, failure rate and fault coverage of component are important factors to the reliability of system. It is, therefore, necessary to develop a highly dependable SBW system architecture to ensure the security of car by using redundancy, decreasing failure rate, or increasing fault coverage.
\end{abstract}

Index Terms-Steering-by-wire (SBW), failure mode and effects analysis (FMEA), markov model, redundancy.

\section{INTRODUCTION}

Rapid development of modern automotive electronics and deep electronic degree make the X-by-wire technology widely used in all aspects of the automobile, such as steering-by-wire, brake-by-wire, suspension-by-wire and throttle-by-wire and so on. X-by-wire technology derived from NASA in 1972 is the first to be used in telex operating system (Fly-by-wire) on space science and technology, which is an important technology of vehicle into autopilot era.

Automotive steering-by-wire system is a safety-critical real-time system. In safety-critical real-time system, the failure of a single component may cause the entire system to a standstill. Thus, fault tolerance is especially important [1]. The reliability of the electrical control system has been continuously improved in the system design, which largely introduces the concept of redundancy. In order to ensure real-time and reliability of the system, in the auto industry, there has been a large-scale Auto Union, aimed at building a scalable electronic architecture (such as AUTOSAR) and a generic, scalable communications system, such as FlexRay, which meets the needs of active safety systems. CAN bus, which is the most commonly used, has drawbacks in fault tolerance and bandwidth. Therefore, the FlexRay is used in the automotive steering-by-wire system [2].

\section{SySTEM DESIGN}

In order to ensure real-time and reliability, and meet the

Manuscript submitted in January 25, 2015; revised April 21, 2016.

The authors are with School of Optical-Electrical and Computer Engineering, University of Shanghai for Science and Technology, Shanghai, 200093, China (e-mail: huzhongyi2010@126.com). requirements of economic practicality, the architecture of steering-by-wire system with fault tolerance is shown in Fig. 1 .

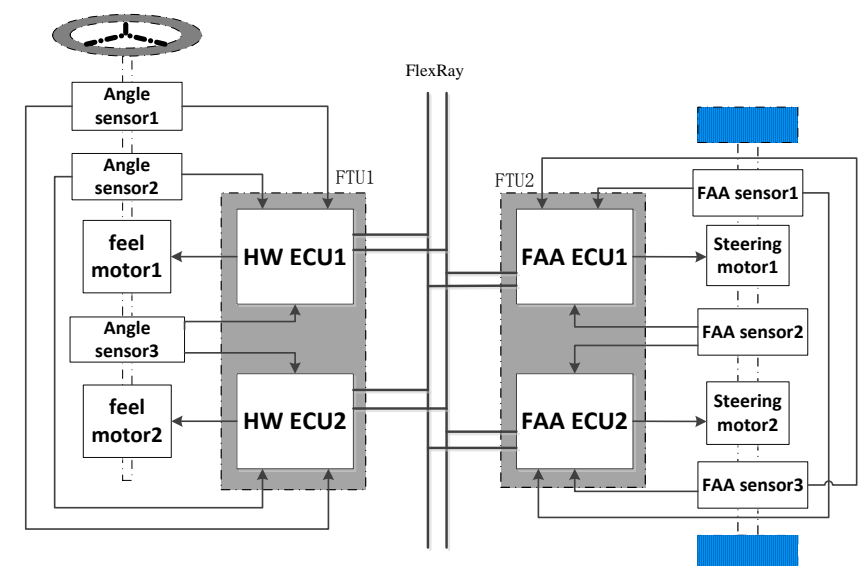

Fig. 1. Block diagram of fault-tolerant architecture of steering-by-wire system.

As shown in Fig. 1, the needs of driver's steering are achieved through three angle sensors. Two HW ECUs respectively receive data from three angle sensors, whose dates will be voted. Then ECUs transmit correct messages to the dual-channel FlexRay bus. Two FAA ECUs receive messages from the bus to control the steering motor, vice versa.

\section{SYSTEM LEVEL FMEA}

To facilitate the presentation, we use IN to represent sensor, and use OUT to represent motor. In order to establish the Markov model of steering-by-wire system, the first step is to develop several system level FMEAs according to the simplified logic block diagram of system. The first FMEA will help to identify first failures in the system, both catastrophic and non-catastrophic. The second FMEA will identify second catastrophic and noncatastrophic failure modes of the new non-catastrophic operational modes of the system defined by the first FMEA. The process will end when all the identified failure modes of an FMEA are catastrophic. To construct the system level FMEA, some simplifying assumptions are postulated:

1) Firstly, each unit is not considered transient failure and permanent failure, which is all defined as the failure rate $\lambda$.

2) Secondly, repair rate $\rho$ of each unit and fault coverage $\mathrm{c}$ are not considered.

Define sensor failure rate as $\lambda_{I N}, \mathrm{ECU}$ failure rate as $\lambda_{E C U}$, and motor failure rate as $\lambda_{\text {OUT }}$. The FMEA tables of steering-by-wire system are shown in Table I-Table V. 
Table I corresponds to the FMEA of first fault of System. The first column of Table I lists the failures of the system state. The second column is the probability of the first column by the state described in the associated event. The third column describes the system failure times described in the first column generated, and the fourth column shows the failure rate of failure. Finally, the fifth column lists the probability of these new systems associated status. Table II corresponds to a second fault system FMEA. The first column of Table II is a non-fault state which corresponds to Table I in the fifth column. The remaining columns of Table II obtain the same manner in Table I. Table II reporting the third failure system and its construction method is same with Table II. Besides it lists the non-fault state from the fifth column of Table II. Table IV, V are constructed the same way as Table I.

TABLE I: SYSTEM LEVEL FMEA FOR FIRST FAILURES

\begin{tabular}{ccccc}
\hline \hline $\begin{array}{c}\text { System state } \\
\text { with no failures }\end{array}$ & $\begin{array}{c}\text { State } \\
\text { probability }\end{array}$ & $\begin{array}{c}\text { First } \\
\text { failure }\end{array}$ & $\begin{array}{c}\text { Failure } \\
\text { rate }\end{array}$ & $\begin{array}{c}\text { State } \\
\text { probabil } \\
\text { ity }\end{array}$ \\
\hline $\begin{array}{c}\text { Sensor normal, } \\
\text { steering motor } \\
\text { normal, ECU } \\
\text { node normal } \\
\text { running }\end{array}$ & $\mathrm{P} 1$ & $\begin{array}{c}\text { Any } \\
\text { sensor } \\
\text { failure }\end{array}$ & $3 \lambda_{I N}$ & $\mathrm{P} 2$ \\
\cline { 2 - 4 } & & $\begin{array}{c}\text { Any ECU } \\
\text { failure }\end{array}$ & $2 \lambda_{E C U}$ & $\mathrm{P} 8$ \\
& & & \\
& & Any motor \\
& failure & $2 \lambda_{O U T}$ &
\end{tabular}

TABLE II: SYSTEM LEVEL FMEA FOR SECOND FAILURES

\begin{tabular}{|c|c|c|c|c|}
\hline $\begin{array}{l}\text { System state } \\
\text { with one } \\
\text { failures }\end{array}$ & $\begin{array}{c}\text { State } \\
\text { probabilit } \\
y\end{array}$ & $\begin{array}{l}\text { Second } \\
\text { failure }\end{array}$ & $\begin{array}{l}\text { Failure } \\
\text { rate }\end{array}$ & $\begin{array}{c}\text { State } \\
\text { probability }\end{array}$ \\
\hline \multirow{3}{*}{$\begin{array}{l}\text { The remaining } \\
\text { two sensors } \\
\text { work properly, } \\
\text { dual-motor } \\
\text { normal, two- } \\
\text { ECU normal }\end{array}$} & \multirow[t]{3}{*}{$\mathrm{P} 2$} & $\begin{array}{l}\text { Any } \\
\text { sensor } \\
\text { failure }\end{array}$ & $2 \lambda_{I N}$ & P3 \\
\hline & & $\begin{array}{l}\text { Any } \\
\text { ECU } \\
\text { failure }\end{array}$ & $2 \lambda_{E C U}$ & $\mathrm{P} 4$ \\
\hline & & $\begin{array}{l}\text { Any } \\
\text { motor } \\
\text { failure }\end{array}$ & $2 \lambda_{O U T}$ & P11 \\
\hline \multirow[t]{3}{*}{$\begin{array}{l}\text { Three sensors } \\
\text { are normal, } \\
\text { two-motor } \\
\text { normal, ECU } \\
\text { single point of } \\
\text { failure }\end{array}$} & \multirow[t]{3}{*}{ P8 } & $\begin{array}{l}\text { The } \\
\text { remainin } \\
\text { g ECU } \\
\text { node } \\
\text { failure }\end{array}$ & $\lambda_{E C U}$ & $\mathrm{PF}$ \\
\hline & & $\begin{array}{l}\text { Any } \\
\text { sensor } \\
\text { failure }\end{array}$ & $3 \lambda_{I N}$ & $\mathrm{P} 4$ \\
\hline & & $\begin{array}{l}\text { Any } \\
\text { motor } \\
\text { failure }\end{array}$ & $2 \lambda_{O U T}$ & P10 \\
\hline \multirow{3}{*}{$\begin{array}{l}\text { The remaining } \\
\text { motor instead } \\
\text { of failing motor } \\
\text { to provide } \\
\text { steering, three } \\
\text { sensors normal, } \\
\text { two ECU } \\
\text { normal }\end{array}$} & \multirow[t]{3}{*}{ P9 } & $\begin{array}{l}\text { The } \\
\text { remainin } \\
\text { g motor } \\
\text { failure }\end{array}$ & $\lambda_{\text {OUT }}$ & $\mathrm{PF}$ \\
\hline & & $\begin{array}{c}\text { Any } \\
\text { sensor } \\
\text { failure }\end{array}$ & $3 \lambda_{I N}$ & P11 \\
\hline & & $\begin{array}{c}\text { Any } \\
\text { ECU } \\
\text { failure } \\
\end{array}$ & $2 \lambda_{E C U}$ & P10 \\
\hline
\end{tabular}

TABLE III: SYSTEM LEVEL FMEA FOR THIRD FAILURES

\begin{tabular}{|c|c|c|c|c|}
\hline $\begin{array}{c}\text { System state } \\
\text { with two } \\
\text { failures }\end{array}$ & $\begin{array}{c}\text { State } \\
\text { probabili } \\
\text { ty } \\
\end{array}$ & $\begin{array}{l}\text { Third } \\
\text { failure }\end{array}$ & Failure rate & $\begin{array}{c}\text { State } \\
\text { probability }\end{array}$ \\
\hline \multirow{3}{*}{$\begin{array}{c}\text { Only one } \\
\text { sensor is } \\
\text { normal, two } \\
\text { electric motors } \\
\text { are normal, } \\
\text { two ECU } \\
\text { normal }\end{array}$} & \multirow[t]{3}{*}{ P3 } & $\begin{array}{c}\text { The } \\
\text { remaining } \\
\text { sensor } \\
\text { failure }\end{array}$ & $\lambda_{I N}$ & $\mathrm{PF}$ \\
\hline & & $\begin{array}{c}\text { Any ECU } \\
\text { failure }\end{array}$ & $2 \lambda_{E C U}$ & P5 \\
\hline & & $\begin{array}{l}\text { Any motor } \\
\text { failure }\end{array}$ & $2 \lambda_{\text {OUT }}$ & $\mathrm{P} 12$ \\
\hline \multirow[t]{3}{*}{$\begin{array}{c}\text { Two sensors } \\
\text { work properly, } \\
\text { dual-motor } \\
\text { normal, ECU } \\
\text { single point of } \\
\text { failure }\end{array}$} & \multirow[t]{3}{*}{$\mathrm{P} 4$} & $\begin{array}{c}\text { Failure of } \\
\text { any one of } \\
\text { the } \\
\text { remaining } \\
\text { sensors } \\
\end{array}$ & $2 \lambda_{I N}$ & P5 \\
\hline & & $\begin{array}{c}\text { Any ECU } \\
\text { failure }\end{array}$ & $\lambda_{E C U}$ & $\mathrm{PF}$ \\
\hline & & $\begin{array}{l}\text { Any motor } \\
\text { failure }\end{array}$ & $2 \lambda_{\text {OUT }}$ & P6 \\
\hline \multirow{3}{*}{$\begin{array}{l}\text { The remaining } \\
\text { two sensors } \\
\text { are normal, the } \\
\text { motor single } \\
\text { point of } \\
\text { failure, double } \\
\text { ECU normal }\end{array}$} & \multirow[t]{3}{*}{ P11 } & $\begin{array}{l}\text { Failure of } \\
\text { any one of } \\
\text { the } \\
\text { remaining } \\
\text { sensors } \\
\end{array}$ & $2 \lambda_{I N}$ & $\mathrm{P} 12$ \\
\hline & & $\begin{array}{l}\text { Any ECU } \\
\text { failure }\end{array}$ & $2 \lambda_{E C U}$ & P6 \\
\hline & & $\begin{array}{l}\text { Any motor } \\
\text { failure }\end{array}$ & $\lambda_{\text {OUT }}$ & $\mathrm{PF}$ \\
\hline \multirow{2}{*}{$\begin{array}{l}\text { Three sensors } \\
\text { normal, motors } \\
\text { single point of } \\
\text { failure, ECU } \\
\text { single point of } \\
\text { failure }\end{array}$} & \multirow[t]{2}{*}{ P10 } & $\begin{array}{l}\text { Any sensor } \\
\text { failure }\end{array}$ & $3 \lambda_{I N}$ & P6 \\
\hline & & $\begin{array}{c}\text { Any motor } \\
\text { or ECU } \\
\text { failure }\end{array}$ & $\lambda_{E C U}+\lambda_{1}$ & $\mathrm{PF}$ \\
\hline
\end{tabular}

TABLE IV: SYSTEM LEVEL FMEA FOR FOURTH FAILURES

\begin{tabular}{|c|c|c|c|c|}
\hline $\begin{array}{c}\text { System state } \\
\text { with three } \\
\text { failures }\end{array}$ & $\begin{array}{l}\text { State } \\
\text { proba } \\
\text { bility }\end{array}$ & $\begin{array}{l}\text { Fourth } \\
\text { Failure }\end{array}$ & Failure rate & $\begin{array}{c}\text { State } \\
\text { probab } \\
\text { ility }\end{array}$ \\
\hline \multirow[t]{2}{*}{$\begin{array}{l}\text { Only one } \\
\text { sensor is } \\
\text { normal, two- } \\
\text { motor normal, } \\
\text { ECU single } \\
\text { point of } \\
\text { failure }\end{array}$} & \multirow[t]{2}{*}{ P5 } & $\begin{array}{l}\text { Failure of } \\
\text { any one of } \\
\text { the } \\
\text { remaining } \\
\text { sensors or } \\
\text { ECU }\end{array}$ & $\lambda_{I N}+\lambda_{E C U}$ & PF \\
\hline & & $\begin{array}{l}\text { Any motor } \\
\text { failure }\end{array}$ & $2 \lambda_{\text {OUT }}$ & P7 \\
\hline \multirow{2}{*}{$\begin{array}{c}\text { Two sensors } \\
\text { work properly, } \\
\text { motor single } \\
\text { point of } \\
\text { failure, ECU } \\
\text { single point of } \\
\text { failure }\end{array}$} & \multirow[t]{2}{*}{ P6 } & $\begin{array}{l}\text { Failure of } \\
\text { any one of } \\
\text { the } \\
\text { remaining } \\
\text { sensors }\end{array}$ & $2 \lambda_{I N}$ & P7 \\
\hline & & $\begin{array}{l}\text { Any motor or } \\
\text { ECU failure }\end{array}$ & $\lambda_{E C U}+\lambda_{O U T}$ & $\mathrm{PF}$ \\
\hline \multirow{2}{*}{$\begin{array}{c}\text { Only one } \\
\text { sensor is } \\
\text { normal, motor } \\
\text { single point of } \\
\text { failure, double } \\
\text { ECU normal }\end{array}$} & \multirow[t]{2}{*}{$\mathrm{P} 12$} & $\begin{array}{l}\text { Any ECU } \\
\text { failure }\end{array}$ & $2 \lambda_{E C U}$ & P7 \\
\hline & & $\begin{array}{l}\text { Any motor or } \\
\text { sensor failure }\end{array}$ & $\lambda_{I N}+\lambda_{O U T}$ & $\mathrm{PF}$ \\
\hline
\end{tabular}

TABLE V: SYSTEM LEVEL FMEA FOR FIFTH FAILURES

\begin{tabular}{ccccc}
\hline $\begin{array}{c}\text { System state } \\
\text { with four } \\
\text { failures }\end{array}$ & $\begin{array}{c}\text { State } \\
\text { probabilit } \\
\text { y }\end{array}$ & Fifth Failure & $\begin{array}{c}\text { System state } \\
\text { with five } \\
\text { failures }\end{array}$ & $\begin{array}{c}\text { State } \\
\text { probabi } \\
\text { lity }\end{array}$ \\
\hline $\begin{array}{l}\text { Only one } \\
\text { sensor is }\end{array}$ & $\mathrm{P} 7$ & $\begin{array}{c}\text { Failure of any } \\
\text { one of the }\end{array}$ & FAILED & PF \\
normal, motor & & remaining & & \\
single point of & & sensors or & & \\
failure, ECU & & ECU or & & \\
single point of & & motor & \\
failure & & & \\
\hline
\end{tabular}




\section{MARKOV MODEL}

Based on the above analysis of FMEA tables, we can build the Markov model on behalf of the system state. Markov model can use a linear homogeneous differential equation to represent.

$$
\dot{P(t)}=\Lambda(t) P(t) \quad P(0)=\left[\begin{array}{lllll}
1 & 0 & 0 & \ldots & 0
\end{array}\right]^{\prime}
$$

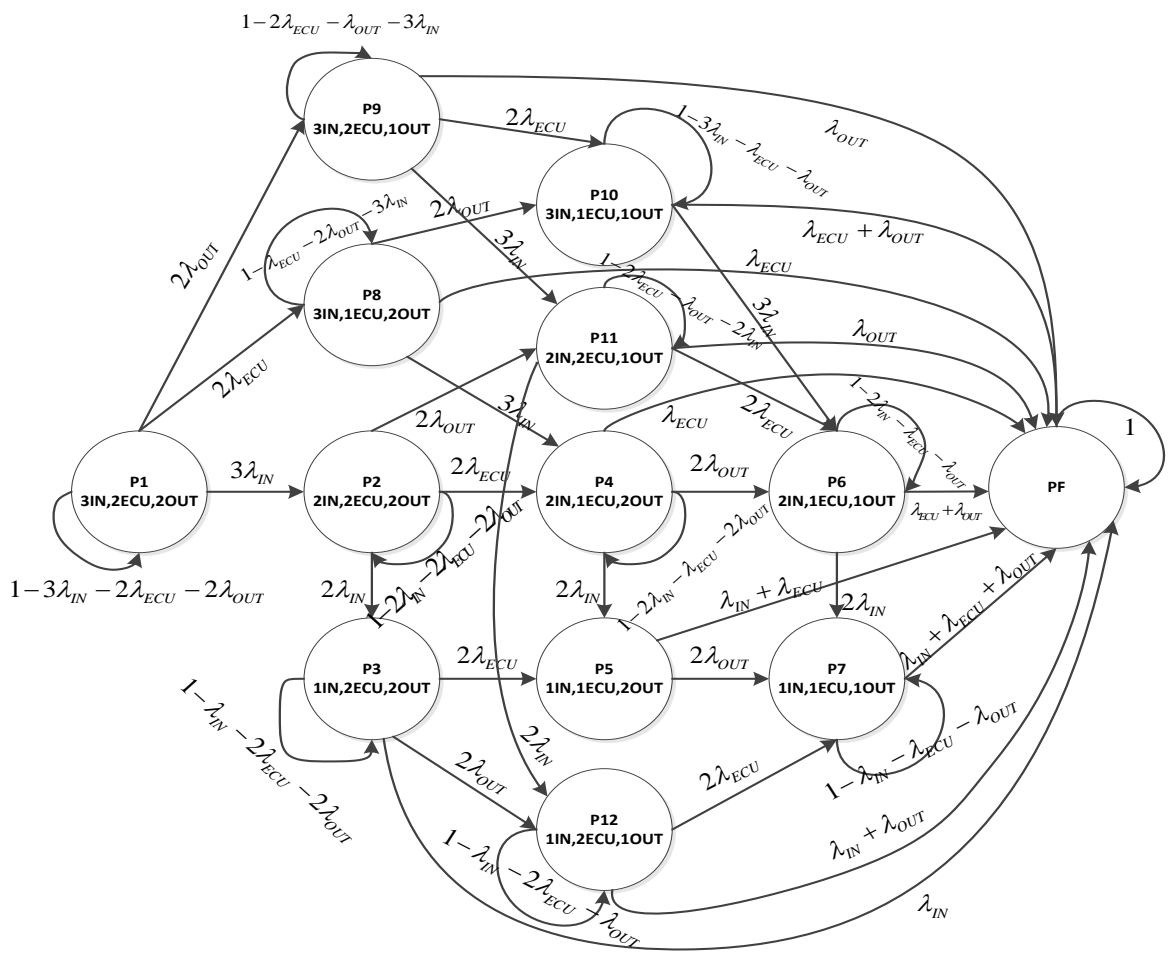

Fig. 2. Markov model of steering-by-wire system.

$P(t)$ is the state probability vector; $P_{k}(t)(K=0,2, \ldots 15)$ represents the probability of system state k at time t. State transition matrix $\Lambda(t)$ can be established by the table above. Each coefficient $\lambda_{i j}$ of matrix can be obtained from the transition probabilities between states.

To facilitate the presentation, we use IN to represent sensor, and use OUT to represent motor. When the system is in good condition, there are three sensors, two ECU nodes and two motors are in operation, which using (3IN, 2ECU, 2OUT) to represent. Other states have same method of analysis. Markov model of the system is shown in Fig. 2.

The initial condition of differential equations is:

$$
\mathrm{P} 1(0)=1, \mathrm{P} 2(0)=\mathrm{P} 3(0)=\mathrm{P} 4(0)=\mathrm{P} 5(0)=\mathrm{P} 6(0)=\mathrm{P} 7
$$

$(0)=\mathrm{P} 8(0)=\mathrm{P} 9(0)=\mathrm{P} 10(0)=\mathrm{P} 11(0)=\mathrm{P} 12(0)=0$. (4-2)

The reliability of the system is:

$$
\begin{array}{r}
\mathrm{R}(\mathrm{t})=\mathrm{P}_{1}(\mathrm{t})+\mathrm{P}_{2}(\mathrm{t})+\mathrm{P}_{3}(\mathrm{t})+\mathrm{P}_{4}(\mathrm{t})+\mathrm{P}_{5}(\mathrm{t})+\mathrm{P}_{6}(\mathrm{t})+\mathrm{P}_{7}(\mathrm{t})+\mathrm{P}_{8}(\mathrm{t})+\mathrm{P}_{9}(\mathrm{t})+ \\
\mathrm{P}_{10}(\mathrm{t})+\mathrm{P}_{11}(\mathrm{t})+\mathrm{P}_{12}(\mathrm{t})
\end{array}
$$

Based on constant differential equations [3], Reliability of the system can be obtained by solving differential equations using matlab solutions.

\section{MODEl PARAMETERS}

According to the failure rate of ECUs, sensors and motors [4] in Table 6 ,we can obtain $\lambda_{I N}=6.06 * 10^{-7}(1 / \mathrm{h})$,

$$
\lambda_{E C U}=6.28 * 10^{-6}(1 / \mathrm{h}), \lambda_{\text {OUT }}=7.9 * 10^{-7}(1 / \mathrm{h}) .
$$

TABLE VI: FAILURE RATE TABLE OF ECUs, SENSORS AND MOTOR

\begin{tabular}{cc}
\hline \hline components & Failure rate $(\mathbf{1 / h})$ \\
\hline sensor & $6.06 * 10^{-7}$ \\
\hline HW ECU,FAA ECU & $6.28 * 10^{-6}$ \\
\hline FlexRay channel & $8.75 * 10^{-7}$ \\
\hline motor & $7.9^{*} 10^{-7}$ \\
\hline \hline
\end{tabular}

Since the steering-by-wire system is safety-critical system, assessment of the failure rate is derived from IEC1508 standard [5] (Safety Integrity Level) SIL. It provides a source to lead to random hardware failures. This is mentioned in Part V of ISO26262 [6].

\section{AnAlysis RESUlT}

A vehicle life time of $5 \times 10^{5}$ hours was considered for simulations, which gives an evaluation time after $1 \times 10^{5} \mathrm{~h}$. Using the parameters of table 6 , which correspond to the assumed nominal failure rate values of ECU, motor and sensor, the relationship between reliability and time yielded by the Markov model is shown in Fig. 3. To demonstrate the superiority of the designed system, we compare the reliability between the redundant steering-by-wire system and non-redundant system.

As is shown in the Fig. 3, the reliability of redundant steering-by-wire system is always higher than that of nonredundant system in the lifespan of vehicle. The design in 
this paper is superior to that of traditional SBW system. The point is redundancy, which is of importance in safety-critical system.

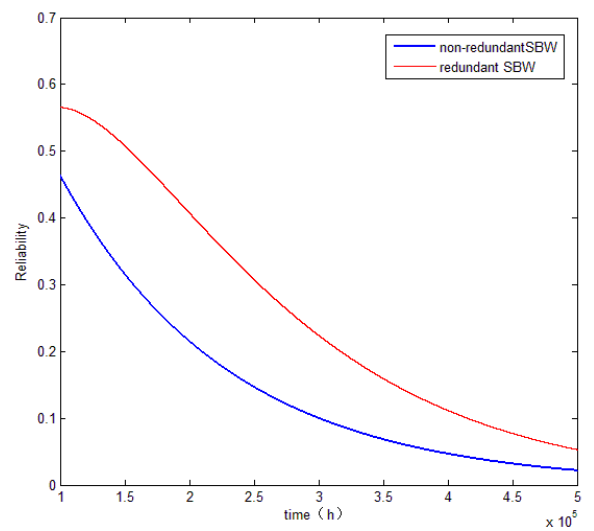

Fig. 3. The reliability diagram of redundant and non-redundant steering-by-wire system.

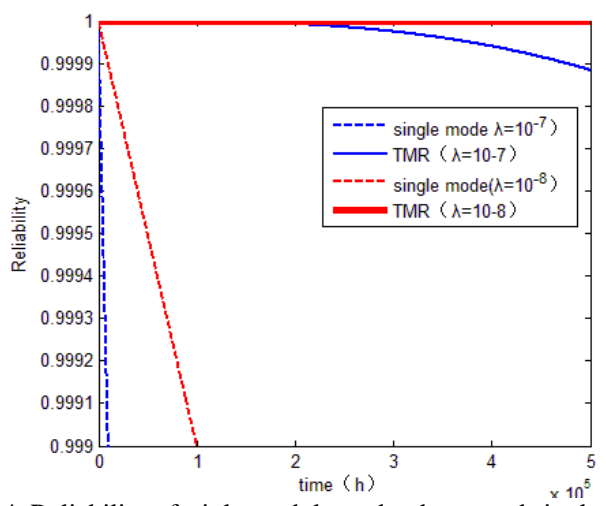

Fig. 4. Reliability of triple modular redundancy and single mode systems under different failure rates.

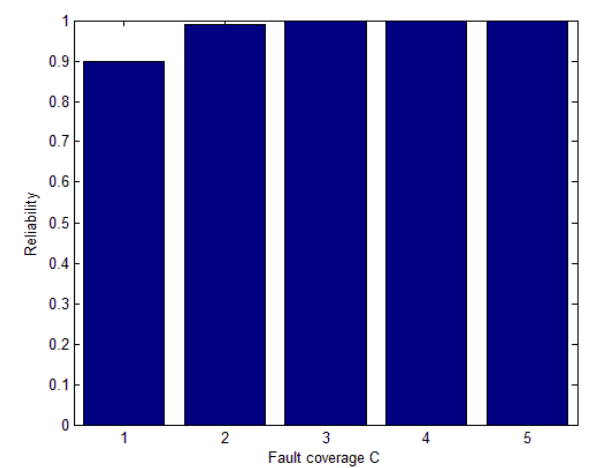

Fig. 5. The impact on the reliability of fault coverage.

A result in this paper is the reliability analysis to study the influence of the presumed failure rates of ECU, sensor and motor. So the failure rate is a factor to the reliability of system. We set $\lambda$ equal $10^{-7}$ and $\underline{\lambda}$ equal $10^{-8}$ respectively to compare the reliability between triple modular redundancy (TMR) system and single modular system to demonstrate the impact of it. The result is shown in Fig. 4.

Fig. 4 shows that, no matter what time, the reliability of triple modular redundant system is higher than that of single-mode system in the lifespan. The lower of failure rate, the higher of reliability.

Fig. 5 shows the reliability analysis for fault coverage c, which is another important factor during design.
The number $1,2,3,4,5$ in the figure correspond to the fault coverage c $0.9,0.99,0.999,0.9999,0.99999$. It is interesting to see that increases in the fault coverage do not produce significant changes in the reliability of system for fault coverages greater than 0.99 . This analysis gives us some insight to how effective the detection algorithm should be.

\section{CONCLUSIONS}

The analysis carried out on the redundant steering-bywire system architecture shows that the influence of redundancy, failure rate and fault coverage in the overall reliability are very important. As seen, the reliability of redundant system is always higher than that of nonredundant system in the lifespan of vehicle. And the reliability of system strongly depends on the failure rate $\lambda$, which is a most important factor. Besides, the factor of fault coverage is also impact the reliability, when it is less than 0.99. Above 0.99, fault coverage is no longer influence the reliability of system any more. So, one way to improve the reliability of system is to introduce the redundancy of components. Another way is to decrease the failure rate of each unit. And we can also do it by improving the detection algorithm to have a fault coverage of 0.99 or greater.

System combined the application of FlexRay bus ensure the properties of real-time, determinacy, reliability and fault tolerance. The system is able to tolerate any failure of the sensors, ECUs and motors, therefore improving the overall stability and reliability of the system. It has certain significance to the future development of automobile technology.

\section{ACKNOWLEDGMENT}

This work was supported by Natural Science Foundation of Shanghai under Grant No.15ZR1429300.

\section{REFERENCES}

[1] F. D. Zhang, Distributed Real-Time Systems, Beijing: Science Press, 2014.

[2] G. Yan, "Research on real-time and fault-tolerance performance of steer-by-wire system based on flexray," Shanghai, University of Shanghai for Science and Technology, 2010.

[3] Ordinary differential equation @ONLINE. [Online]. Available: http://www.mathworks.se/help/matlab/ordinary-differential equations.html

[4] R. Hammett and P. Babcock, "Achieving $10^{-9}$ dependability with drive-by-wire systems," in Proc. SAE 2003 World Congress and Exhibition, Detroit (USA), 2003.

[5] J. Brazendale, "Iec 1508: Functional safety: Safety-related systems," in Proc. Software Engineering Standards Symposium, Aug 1995, pp. 8-17.

[6] Road Vehicles — Functional Safety, Geneva, Switzerland, 2011.

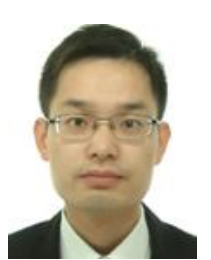

Zhongyi Hu was born in 1992. He received his master degree in instrument and meter from University of Shanghai for Science and Technology, China in 2016.

His research interests are fieldbus and automotive electronics, majoring in automation. 